\title{
Cadmium and Cobalt Desorption Kinetics from Soil Clays: Effect of Sorption Period
}

\author{
Ronald G. McLaren,* Clare A. Backes, Andrew W. Rate, and Roger S. Swift
}

\begin{abstract}
Soil solution metal concentrations and hence metal bioavailability are controlled by sorption-desorption reactions at the surfaces of soil colloids. Compared with the numerous studies on sorption of metals by soils, there are relatively few that examine desorption, and even fewer that have measured desorption kinetics. The objective of this study was, using techniques and models developed previously for studies with synthetic oxides, to examine the effect of sorption period on the subsequent desorption kinetics of $\mathrm{Cd}$ and $\mathrm{Co}$ from two natural soil clay fractions. Cobalt was less readily desorbed from the clay fractions than Cd, but with both metals and clay fractions, increases in sorption period were accompanied by substantial decreases in the proportions of sorbed metal desorbed. As with the oxides studied previously, desorption kinetics for $\mathrm{Cd}$ and Co sorbed onto clay fractions were found to be described well by both a two-site first-order model and a model involving a lognormal distribution of first-order rate constants. Reaction half-lives derived from the models suggested a movement of $\mathrm{Cd}$ and $\mathrm{Co}$ to slower desorption reactions with increasing sorption period. However, some caution should be used in interpreting such parameters.
\end{abstract}

T IS GENERALly ACCEPTED that soil solution metal con1 centrations, and hence metal bioavailability and toxicity, are most likely to be controlled by sorptiondesorption reactions at the surfaces of soil colloidal materials (Swift and McLaren, 1991). Compared with the numerous published studies on sorption of metals by soils and soil constituents, however, there are relatively few that examine desorption, and even fewer that have measured desorption kinetics. The only previous studies that appear to have examined metal desorption

R.G. McLaren and C.A. Backes, Dep. of Soil Science, P.O. Box 84 , Lincoln Univ., Canterbury, New Zealand; A.W. Rate, Soil Science and Plant Nutrition Group, Univ. of Western Australia, Nedlands, W.A. 6907; and R.S. Swift, CSIRO Division of Soils, Private Bag No. 2, Glen Osmond, South Australia 5064. Received 27 Nov. 1995. *Corresponding author (mclaren@lincoln.ac.nz).

Published in Soil Sci. Soc. Am. J. 62:332-337 (1998). kinetics from soil (Kuo and Mikkelsen, 1980 [Zn]; Lehmann and Harter, 1984 [Cu]; Dang et al., 1994 [Zn]) have all used complexing agents (ethylenediamine tetraacetic acid [EDTA], diethylenetriamine pentaacetic acid [DTPA], or sodium citrate) to "desorb" metals from the soil. Although it can be argued that natural complexing agents play an important role in solubilizing metals in soil, the use of relatively high concentrations of synthetic complexing agents to stimulate desorption is likely to produce substantially enhanced amounts of desorption and faster desorption rates than would be likely under normal soil conditions. For example, Lehmann and Harter (1984) showed clearly that rates and amounts of $\mathrm{Cu}$ desorption from soil were strongly influenced by the nature and concentration of the complexing agent used. In a previous study (Backes et al., 1995), we examined the kinetics of $\mathrm{Cd}$ and Co desorption from four synthetically prepared $\mathrm{Fe}$ and $\mathrm{Mn}$ oxides using a technique that involves desorption into a weak electrolyte solution $\left[0.01 M \mathrm{Ca}\left(\mathrm{NO}_{3}\right)_{2}\right]$. We suggest that such a technique is more likely to simulate metal desorption into natural soil solution than the use of synthetic complexing agents.

Synthetically prepared oxides, such as those used by Backes et al. (1995), are often used as models for naturally occurring oxides (e.g., Bruemmer et al., 1988; Barrow et al., 1989), and by extension, as models for the surface properties of whole soils. It was observed with some oxides that increasing the length of sorption period before measuring desorption caused a decrease in the proportions of $\mathrm{Cd}$ or $\mathrm{Cd}$ subsequently desorbed. Kinetic examination of the data suggested that an increased sorption period resulted in movement of sorbed $\mathrm{Cd}$ or Co ions to sites with slower desorption reactions, possibly involving changes in both chemical and diffusion reaction rates.

Due to their different modes of formation, however, there are unavoidable differences between natural and 
synthetic oxides and therefore synthetic oxides may not be appropriate models for natural soils. The use of synthetic oxides as models for soil processes also ignores the complex interactions that can occur between the oxides and other types of soil constituents. For example, organic matter can coat, or be coated by, oxides, or it may even be incorporated into the surface hydroxyl sheets of oxide minerals (Tate and Theng, 1980). Both types of constituent may also be present in soils either as surface coatings on other mineral particles or more intimately associated with soil phyllosilicate minerals. Tiller et al. (1984) have suggested that soil clay fractions provide a convenient means of studying the reactive adsorption surfaces of whole soils.

In this study, using the same techniques and models developed for studies with synthetic oxides (Backes et al., 1995), we examined the kinetics of Co and Cd desorption from two natural soil clay fractions. In particular, we examined the effect of sorption contact period on subsequent desorption of $\mathrm{Co}$ and $\mathrm{Cd}$ from the clays. Such information is required for improving our knowledge of, and predicting the fate of, metals in soils, particularly in relation to their bioavailability to plants and soil biota.

\section{MATERIALS AND METHODS}

\section{Soils and Clay Fractions}

The soils used in this study were a Craigieburn silt loam and a Wakanui silt loam. Samples of topsoil $(0-15 \mathrm{~cm})$ were collected from pasture sites in the South Island of New Zealand, air dried, and ground to pass a $2-\mathrm{mm}$ sieve. The Craigieburn soil is a Typic Dystrochrept formed from greywacke loess and the Wakanui soil is an Aquic Ustochrept developed on fine greywacke alluvium.

Clay fractions $(<2 \mu \mathrm{m})$ were separated from the soil samples by sedimentation (Gee and Bauder, 1986) and freezedried before use. Some properties of the clay fractions are shown in Table 1.

\section{Sorption-Desorption Procedures}

Sorption-desorption procedures were essentially the same as those described by Backes et al. (1995). Samples of clay $(50 \mathrm{mg})$ were weighed into $35-\mathrm{mL}$ polypropylene vials and 20 $\mathrm{mL}$ of solution added to give final concentrations of $5 \times 10^{-4}$ $M \mathrm{Co}\left(\mathrm{NO}_{3}\right)_{2}$ or $10^{-4} M \mathrm{Cd}\left(\mathrm{NO}_{3}\right)_{2}$ in a background electrolyte solution of $0.01 M \mathrm{Ca}\left(\mathrm{NO}_{3}\right)_{2}$. Solution pH values were adjusted to $\approx 7.0$ by the addition of small predetermined volumes of saturated $\mathrm{Ca}(\mathrm{OH})_{2}$ solution. After shaking for $24 \mathrm{~h}$, the samples were allowed to stand for either $1 \mathrm{wk}$ or 12 to $16 \mathrm{wk}$ (with periodic shaking) before the contents of the vial were filtered (by injection) through a weighed 25-mm-diam. Swinnex filter holder containing a $0.45-\mu \mathrm{m}$ Millipore cellulose ester filter (Millipore Corp., Bedford, MA). The concentration of
Co or $\mathrm{Cd}$ in the filtrate was determined so that both the amounts of metal sorbed and the amounts entrained could be determined. The amounts of entrained metal were subsequently subtracted from the amounts present in the first desorption fraction. Desorption of metals was induced by continuous peristaltic pumping of $0.01 M \mathrm{Ca}\left(\mathrm{NO}_{3}\right)_{2}$ through the clay on the filter at a flow rate of 2.5 to $3.0 \mathrm{~mL} \mathrm{~min}{ }^{-1}$. The eluent was adjusted to $\mathrm{pH} 7.0$ and the system was maintained at $20^{\circ} \mathrm{C}$ throughout the whole desorption period (up to $7 \mathrm{~h}$ ). Eluate fractions were collected every $120 \mathrm{~s}$ using a fraction collector. Cobalt or $\mathrm{Cd}$ concentrations were measured in all the initial fractions from each desorption run; however, as the experiments progressed and the rate of change of metal concentrations decreased, fewer fractions were analyzed. Each experimental treatment (i.e., clay-sorption period combination) was run in duplicate.

Although filter flow methods such as the one described above have some advantages over batch techniques for kinetic studies, they are by no means completely without potential problems. Sparks (1989) has discussed some of these concerns, which include the possibility of preferential flow through the material on the filter, and the occurrence of film and interparticle diffusion, which can introduce artifacts, particularly when comparing the kinetics of different materials. In this study, as a result of the small amounts used, the soil clays formed extremely thin layers on the filter so that such effects should have been minimized. However, no check was made to determine whether desorption kinetics were altered substantially by the flow rate of the $\mathrm{Ca}\left(\mathrm{NO}_{3}\right)_{2}$ through the filter.

Another potential source of error associated with use of the filter flow method is in dealing with the metal contained in the entrained solution following sorption. In a study examining B sorption-desorption, Carski and Sparks (1985) showed that entrained solution was not removed via miscible displacement, but constantly diluted until it was negligible. In our study, however, the amounts of entrained solution were relatively small and accounted for between only one-tenth and one-fifth of the volume collected for the first desorption data point. In addition. the amount of entrained metal was generally less than one-tenth of the total metal collected in the first desorption fraction. It was therefore considered that subtraction of the entrained metal from the first data point was unlikely to introduce a substantial error into the data.

\section{Cobalt and Cadmium Analysis}

Cobalt and Cd concentrations in equilibrium solutions and eluates were determined by flame or graphite furnace atomic absorption spectrophotometry. For Cd determinations by graphite furnace, to overcome interference from $\mathrm{Ca}$, ammonium phosphate $(0.43 M)$ was added to the samples (Kaiser et al., 1981). Detection limits were 0.001 and $0.005 \mu \mathrm{g} \mathrm{mL}^{-1}$ for $\mathrm{Cd}$ and $\mathrm{Co}$, respectively.

\section{Numerical Methods}

In a previous study with synthetic oxides (Backes et al., 1995), desorption kinetics for both $\mathrm{Cd}$ and $\mathrm{Co}$ were found to

Table 1. Properties of the Craigieburn and Wakanui clay $(<2-\mu \mathrm{m})$ fractions.

\begin{tabular}{|c|c|c|c|c|c|}
\hline \multirow[b]{2}{*}{ Sample } & \multirow[b]{2}{*}{ Organic C } & \multicolumn{2}{|c|}{$\mathbf{F e} \dagger$} & \multirow[b]{2}{*}{$\mathbf{M n} \ddagger$} & \multirow[b]{2}{*}{ Dominant mineralogy } \\
\hline & & $\begin{array}{c}\text { Short-range } \\
\text { order }\end{array}$ & Crystalline & & \\
\hline & $\longrightarrow$ & $-\mathrm{g} \mathrm{kg}^{-1}$ & 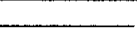 & $\mathbf{m g ~ k g ^ { - 1 }}$ & \\
\hline $\begin{array}{l}\text { Craigieburn } \\
\text { Wakanui }\end{array}$ & $\begin{array}{l}68 \\
67\end{array}$ & $\begin{array}{r}14.7 \\
5.9\end{array}$ & $\begin{array}{r}12.7 \\
0.3\end{array}$ & $\begin{array}{r}63 \\
293\end{array}$ & $\begin{array}{l}\text { vermiculite-chlorites, some goethite } \\
\text { illite-hydrous micas }\end{array}$ \\
\hline
\end{tabular}

† Short-range order and crystalline materials extracted as described by Blakemore et al. (1987) and Shuman (1982), respectively.

$\ddagger$ Sum of Mn extracted by both Fe extractants. 
Table 2. Cadmium sorbed by clay fractions prior to desorption and proportions desorbed after $1.8 \times 10^{4} \mathrm{~s}(5 \mathrm{~h})(\mathrm{Cd}$ added $=$ $40 \mathrm{mmol} \mathrm{kg}^{-1}$ ).

\begin{tabular}{|c|c|c|c|c|}
\hline Sample & $\begin{array}{c}\text { Sorption } \\
\text { period }\end{array}$ & pH & Cd sorbed & $\begin{array}{c}\text { Desorption after } \\
1.8 \times 10^{4} \mathrm{~s}\end{array}$ \\
\hline & $\mathbf{w k}$ & & $\mathrm{mmol} \mathrm{kg}^{-1}$ & $\%$ \\
\hline Craigieburn & $\begin{array}{r}1 \\
1 \\
12 \\
12\end{array}$ & $\begin{array}{l}7.0 \\
6.9 \\
7.0 \\
6.9\end{array}$ & $\begin{array}{l}\mathbf{3 7 . 3 6} \\
\mathbf{3 5 . 6 7} \\
\mathbf{3 5 . 5 8} \\
\mathbf{3 5 . 1 4}\end{array}$ & $\begin{array}{l}49 \\
51 \\
36 \\
37\end{array}$ \\
\hline Wakanui & $\begin{array}{r}1 \\
1 \\
16 \\
16\end{array}$ & $\begin{array}{l}7.4 \\
7.5 \\
7.2 \\
7.3\end{array}$ & $\begin{array}{l}36.47 \\
37.81 \\
36.21 \\
36.56\end{array}$ & $\begin{array}{l}70 \\
71 \\
44 \\
47\end{array}$ \\
\hline
\end{tabular}

be described well by assuming the occurrence of two simultaneous first-order reactions, or by a continuous distribution of reaction sites, distributed lognormally with respect to a firstorder rate constant. The same two models were used in this study for $\mathrm{Cd}$ and Co desorption from soil clays. The mathematical expressions of these models are as follows:

1. Two-site model (Willis et al., 1970):

$$
C_{M}=C_{1} \exp \left(-k_{1} t\right)+C_{2} \exp \left(-k_{2} t\right)
$$

where $C_{\mathrm{M}}$ is the concentration of metal ion sorbed to the clay at time $t, C_{1}$ and $C_{2}$ are the initial concentrations $(t=0)$ of metal ion bound to sites with first-order desorption rate constants $k_{1}$ and $k_{2}$, respectively. It was assumed that all metal ions would eventually $(t=\infty)$ desorb, i.e., $C_{1}+C_{2}=$ metal sorbed (Tables 2 and 3 ). Fitting to experimental data was achieved by optimizing values for $C_{1}, k_{1}$, and $k_{2}$. Since the total metal sorbed at $t=0$ was fixed by the experimental data, $C_{2}$ was, in effect, fixed by the fitted value of $C_{1}$.

2. Lognormal model (Rate et al., 1992):

$$
C_{\mathrm{M}}=\frac{C_{\mathrm{des}}}{\sigma \sqrt{2 \pi}} \int_{-4 \sigma}^{+4 \sigma} \exp \left[\frac{-1}{2}\left(\frac{\kappa-\mu}{\sigma}\right)^{2}\right] \exp \left(-\mathrm{e}^{\kappa} t\right) \mathrm{d} \kappa
$$

where $C_{\text {des }}$ is the amount of metal that desorbs, $\mu$ is the mean of the normal distribution in $\ln k, \sigma$ is the corresponding standard deviation, and $\kappa(=\ln k)$ is the variable of integration. As with Eq. [1], it was assumed that all metal ions would eventually desorb, i.e., $C_{\mathrm{des}}=$ metal sorbed at $t=0$ (Tables 2 and 3 ).

The numerical methods used to fit experimental data to these models have been described by Backes et al. (1995).

\section{RESULTS AND DISCUSSION}

The two clay fractions had similar organic $\mathrm{C}$ contents but differed in their dominant mineralogy (Table 1). In addition to differences between the fractions in the types

Table 3. Cobalt sorbed by clay fractions prior to desorption and proportions desorbed after $1.8 \times 10^{4} \mathrm{~s}(5 \mathrm{~h})(\mathrm{Co}$ added $=\mathbf{2 0 0}$

\begin{tabular}{|c|c|c|c|c|}
\hline Sample & $\begin{array}{c}\text { Sorption } \\
\text { period }\end{array}$ & pH & Co sorbed & $\begin{array}{c}\text { Desorption after } \\
1.8 \times 10^{4} \mathrm{~s}\end{array}$ \\
\hline & wk & & mmol $\mathbf{k g}^{-1}$ & $\%$ \\
\hline \multirow[t]{4}{*}{ Craigieburn } & $\mathbf{1}$ & 6.9 & 189.54 & 37 \\
\hline & 1 & 6.9 & 190.72 & 37 \\
\hline & 12 & 7.1 & 180.03 & 19 \\
\hline & 12 & 6.9 & 176.98 & 17 \\
\hline \multirow[t]{4}{*}{ Wakanui } & $\mathbf{1}$ & 6.9 & 188.18 & 29 \\
\hline & $\mathbf{1}$ & 7.1 & 183.09 & 29 \\
\hline & 13 & 7.3 & $\mathbf{1 8 5 . 2 9}$ & 12 \\
\hline & 13 & 7.1 & 183.77 & 16 \\
\hline
\end{tabular}
mmol $\mathrm{kg}^{-1}$ ). of phyllosilicate minerals present, the Craigieburn clay had substantially higher concentrations of both shortrange order and crystalline Fe materials than the Wakanui clay (Table 1). Neither clay fraction contained significant quantities of Mn oxides.

At $\mathrm{pH} \approx 7.0$, the clay fractions sorbed $\approx 90 \%$ of the $\mathrm{Cd}$ or $\mathrm{Co}$ added. There were no substantial differences between the two clay fractions in the concentrations of $\mathrm{Cd}$ or Co sorbed, or between those samples equilibrated for different lengths of time (Tables 2 and 3). The higher concentrations of Co sorbed compared with Cd simply reflects the relative concentrations of the two metals in the initial solutions. The lack of a difference in the sorption of metals between the two clay fractions may be a result of their similar organic $C$ contents. Organic materials are known to provide large numbers of sites capable of binding metals (Stevenson, 1982; Swift and McLaren, 1991), and in many soils may dominate sorption. This may be particularly true at the relatively high $\mathrm{pH}(\approx 7.0)$ used in this study. Metal sorption by organic materials such as humic acids increases with increasing pH (Kerndorff and Schnitzer, 1980).

The concentrations of $\mathrm{Co}$ and $\mathrm{Cd}$ used in this study were dictated to a large extent by the analytical methods used for their determination. As a result, the concentrations of the metals sorbed by the clays were considerably higher than concentrations found in most natural unpolluted soils. However, in soils heavily polluted with trace metals, concentrations of $\mathrm{Cd}$ as high as 13 to $15 \mathrm{mmol}$ $\mathrm{kg}^{-1}$ soil and of Co as high as 2.0 to $2.5 \mathrm{mmol} \mathrm{Co} \mathrm{kg}{ }^{-1}$ soil have been recorded (Kabata-Pendias and Pendias, 1992). These figures will translate to substantially higher values in the soil clay fraction where most metals tend to be concentrated.

In spite of the similarity in $\mathrm{Cd}$ and Co sorption between the two clay fractions, there were considerable differences in the proportions of metals ions desorbed (Tables 2 and 3). Even though greater concentrations of Co were sorbed than $\mathrm{Cd}$, lower proportions of sorbed Co were desorbed back into solution $(12-37 \%$ compared with $36-71 \%$ ). There were also substantial differences in desorption with increasing time of equilibration prior to desorption. With both $\mathrm{Cd}$ and $\mathrm{Co}$, increasing the sorption period from $1 \mathrm{wk}$ to between 12 and $16 \mathrm{wk}$ decreased the subsequent desorption of the metals from both clay fractions (Tables 2 and 3 ). With $\mathrm{Cd}$, however, greater proportions of the sorbed metal were desorbed from the Wakanui than the Craigieburn clay, whereas the reverse was true for Co. These differences no doubt reflect the differences in composition between the two clay fractions, particularly in short-range order and crystalline Fe materials (Table 1), and differences between $\mathrm{Cd}$ and $\mathrm{Co}$ in their affinity for different soil components. For example, Co has been shown to have a greater affinity than Cd for humic substances (Tipping and Hurley, 1992) and the crystalline $\mathrm{Fe}$ mineral goethite (Forbes et al., 1976), whereas Cd has a greater affinity than Co for the short-range order Fe mineral ferrihydrite (Kinniburgh et al., 1976). The effect of contact period on subsequent metal desorption is similar to that observed previously for both $\mathrm{Cd}$ and $\mathrm{Co}$ sorbed by goe- 

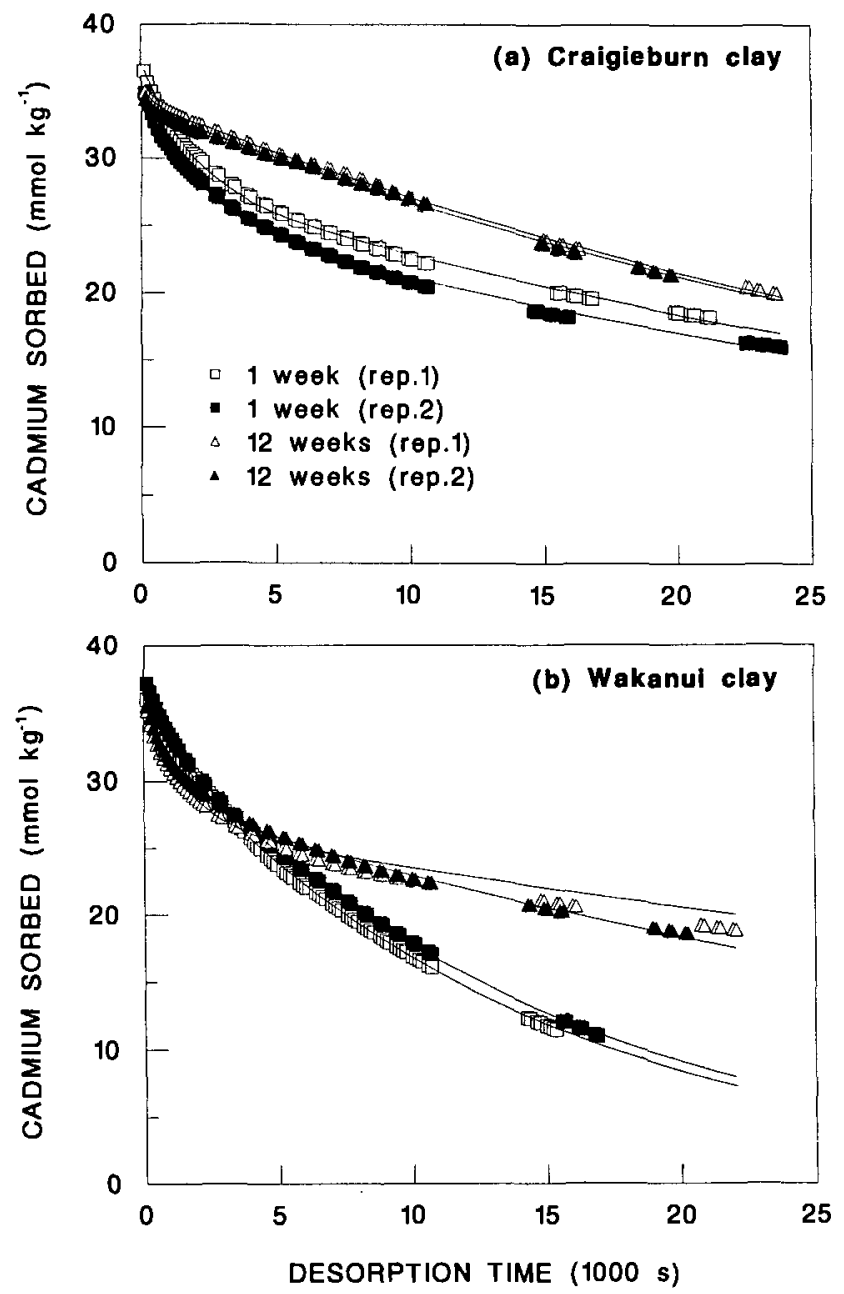

Fig. 1. Effect of initial sorption period on desorption of $\mathrm{Cd}$ from soil clay fractions (symbols $=$ experimental observations, lines $=$ fits to Eq. [1]).

thite (Backes et al., 1995). Similar effects have also been observed for desorption of $\mathrm{Cu}$ from humic acid complexes (Rate et al., 1993). McLaren et al. (1986) have also observed a decrease in the isotopic exchangeability of Co sorbed by humic acid with increasing contact period.

Figures 1 and 2 show plots of $\mathrm{Cd}$ or Co sorbed by the clay fractions $\left(C_{\mathrm{M}}\right)$ vs. length of desorption period
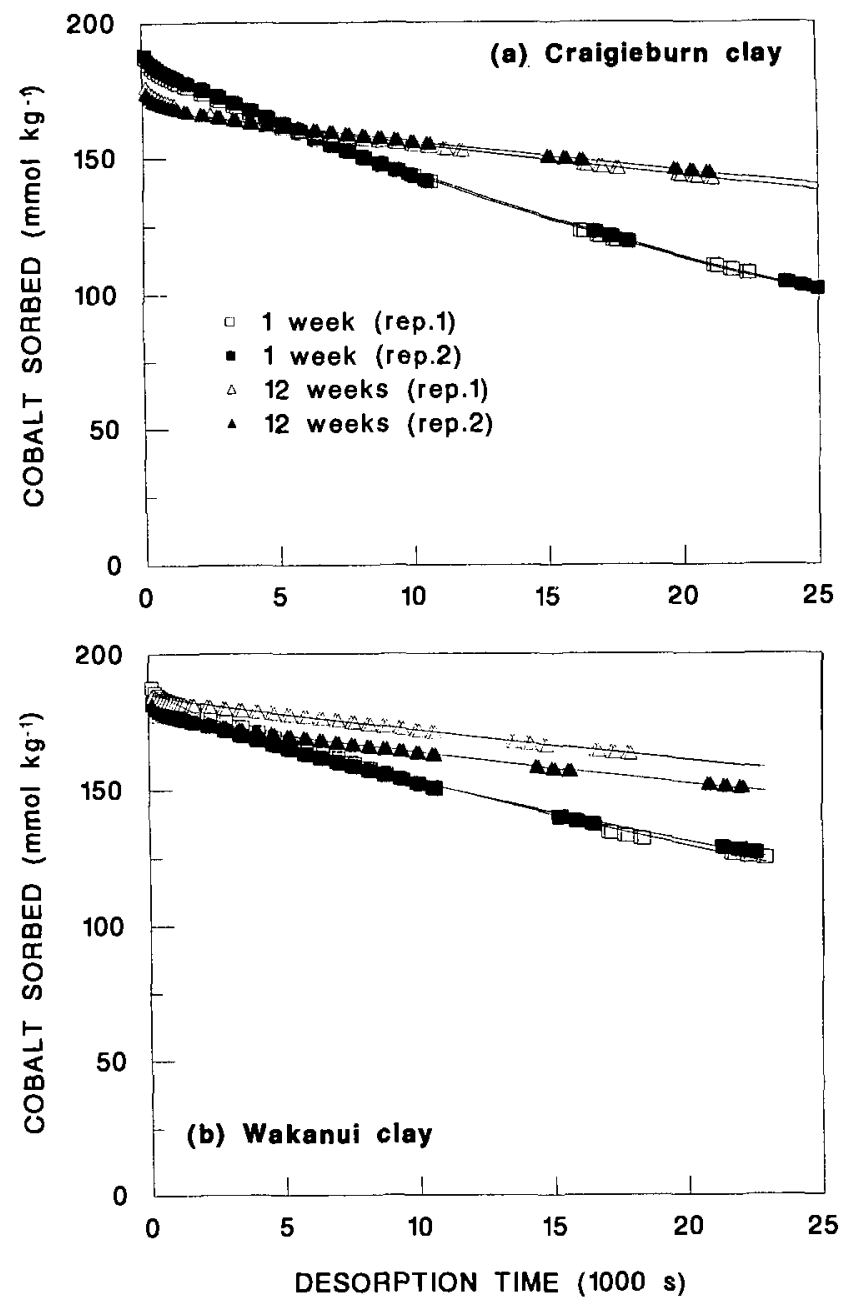

Fig. 2. Effect of initial sorption period on desorption of Co from soil clay fractions (symbols $=$ experimental observations, lines $=$ fits to Eq. [1]).

$(t)$. Since there were small differences in $\mathrm{pH}$ between experimental runs, individual replicates are shown; however, replication was generally good. The lines on the figures are drawn according to Eq. [1], which assumes that desorption was controlled by two simultaneous first-order reactions. Excellent agreement between observed and predicted values were obtained, with $R^{2}$ values all $>99.5 \%$ (Tables 4 and 5 ). However, it should

Table 4. Fitted parameters derived from application of Eq. [1] and [2] to Cd desorption kinetics data for soil clays $\left(C_{1}\right.$ and $C_{2}$ are initial concentrations; $t_{0.5}(k)$ is the half-life of the first-order rate reaction with rate constant $k$, and $C_{1}+C_{2}$ is the total amount of metal sorbed at time $=0)$.

\begin{tabular}{|c|c|c|c|c|c|c|c|c|c|}
\hline \multirow[b]{2}{*}{ Sample } & \multirow[b]{2}{*}{$\begin{array}{c}\text { Sorption } \\
\text { period }\end{array}$} & \multicolumn{6}{|c|}{ First-order two-site Eq. [1] } & \multicolumn{2}{|c|}{$\begin{array}{c}\text { First-order } \\
\text { lognormal Eq. [2] }\end{array}$} \\
\hline & & $C_{1}$ & $t_{0.5}\left(k_{1}\right)$ & $C_{2}$ & $t_{0, s}\left(k_{2}\right)$ & $\boldsymbol{R}^{2}$ & $\begin{array}{c}C_{2} \text { as \% } \\
\text { of } C_{1}+C_{2} \\
\end{array}$ & $\begin{array}{l}\text { Mean } \\
t_{0.5}(k)\end{array}$ & $\boldsymbol{R}^{2}$ \\
\hline & $\mathbf{w k}$ & $\mathbf{m m o l ~} \mathbf{k g}^{-1}$ & h & mmol $\mathbf{k g}^{-1}$ & h & - & - & $\mathbf{h}$ & $\%$ \\
\hline Craigieburn & $\begin{array}{r}1 \\
1 \\
12 \\
12\end{array}$ & $\begin{array}{l}\mathbf{8 . 9 8} \\
9.52 \\
1.42 \\
1.42\end{array}$ & $\begin{array}{l}0.33 \\
0.37 \\
0.07 \\
0.04\end{array}$ & $\begin{array}{l}\mathbf{2 8 . 3 8} \\
\mathbf{2 6 . 2 4} \\
\mathbf{3 4 . 1 6} \\
\mathbf{3 3 . 7 2}\end{array}$ & $\begin{array}{l}9.00 \\
9.00 \\
8.40 \\
8.40\end{array}$ & $\begin{array}{l}99.8 \\
99.7 \\
99.9 \\
99.9\end{array}$ & $\begin{array}{l}\mathbf{7 6 . 0} \\
\mathbf{7 3 . 4} \\
96.0 \\
\mathbf{9 5 . 9}\end{array}$ & $\begin{array}{r}6.52 \\
5.68 \\
10.10 \\
10.83\end{array}$ & $\begin{array}{r}100.0 \\
100.0 \\
98.9 \\
97.9\end{array}$ \\
\hline Wakanui & $\begin{array}{r}1 \\
1 \\
16 \\
16\end{array}$ & $\begin{array}{l}2.85 \\
3.47 \\
9.25 \\
7.83\end{array}$ & $\begin{array}{l}0.26 \\
0.16 \\
0.28 \\
0.25\end{array}$ & $\begin{array}{l}33.63 \\
34.34 \\
26.95 \\
28.73\end{array}$ & \begin{tabular}{r|r|}
2.78 \\
2.91 \\
14.27 \\
8.60
\end{tabular} & $\begin{array}{r}100.0 \\
100.0 \\
99.6 \\
99.7\end{array}$ & \begin{tabular}{|l|l|}
92.2 \\
90.8 \\
74.4 \\
78.6
\end{tabular} & $\begin{array}{l}2.60 \\
2.66 \\
8.80 \\
7.66\end{array}$ & $\begin{array}{l}99.8 \\
99.4 \\
99.8 \\
99.9\end{array}$ \\
\hline
\end{tabular}


Table 5. Fitted parameters derived from application of Eq. [1] and [2] to Co desorption kinetics data for soil clays $\left(C_{1}\right.$ and $C_{2}$ are initial concentrations; $t_{0.5}(k)$ is the half-life of the first-order rate reaction with rate constant $k$, and $C_{1}+C_{2}$ is the total amount of metal sorbed at time $=0$ ).

\begin{tabular}{|c|c|c|c|c|c|c|c|c|c|}
\hline \multirow[b]{2}{*}{ Sample } & \multirow[b]{2}{*}{$\begin{array}{c}\text { Sorption } \\
\text { period }\end{array}$} & \multicolumn{6}{|c|}{ First-order two-site Eq. [1] } & \multicolumn{2}{|c|}{$\begin{array}{c}\text { First-order } \\
\text { lognormal Eq. [2] }\end{array}$} \\
\hline & & $C_{1}$ & $t_{0.5}\left(k_{1}\right)$ & $C_{2}$ & $t_{0.5}\left(k_{2}\right)$ & $R^{2}$ & $\begin{array}{c}C_{2} \text { as \% } \\
\text { of } C_{1}+C_{2}\end{array}$ & $\begin{array}{l}\text { Mean } \\
t_{0,5}(k)\end{array}$ & $\boldsymbol{R}^{2}$ \\
\hline & $\mathbf{w k}$ & $\mathrm{mmol} \mathrm{kg}^{-1}$ & $\mathbf{h}$ & mmol kg-1 & $\mathbf{h}$ & $\ldots$ & - & h & $\%$ \\
\hline Craigieburn & $\begin{array}{r}1 \\
1 \\
12 \\
12\end{array}$ & $\begin{array}{r}6.45 \\
6.62 \\
11.88 \\
8.99\end{array}$ & $\begin{array}{l}\text { 0.05 } \\
0.07 \\
0.13 \\
\mathbf{0 . 0 5}\end{array}$ & $\begin{array}{l}183.09 \\
184.11 \\
168.16 \\
167.99\end{array}$ & $\begin{array}{r}8.02 \\
8.02 \\
24.23 \\
26.57\end{array}$ & $\begin{array}{r}100.0 \\
99.9 \\
99.7 \\
99.8\end{array}$ & $\begin{array}{l}96.6 \\
96.5 \\
93.4 \\
94.9\end{array}$ & $\begin{array}{r}9.21 \\
8.80 \\
149.43 \\
226.17\end{array}$ & $\begin{array}{l}99.3 \\
99.5 \\
98.4 \\
97.9\end{array}$ \\
\hline Wakanui & $\begin{array}{r}1 \\
1 \\
13 \\
13\end{array}$ & $\begin{array}{l}6.24 \\
4.24 \\
1.87 \\
7.47 \\
\end{array}$ & $\begin{array}{l}\text { 0.28 } \\
\text { 0.10 } \\
\text { o.03 } \\
\mathbf{0 . 0 9}\end{array}$ & $\begin{array}{l}181.9 \\
178.85 \\
183.43 \\
176.30\end{array}$ & $\begin{array}{l}11.34 \\
12.43 \\
29.81 \\
26.57\end{array}$ & $\begin{array}{l}99.8 \\
99.9 \\
99.9 \\
99.8\end{array}$ & $\begin{array}{l}97.7 \\
98.7 \\
99.0 \\
95.9\end{array}$ & \begin{tabular}{r|r|}
14.60 \\
17.16 \\
78.42 \\
171.57
\end{tabular} & $\begin{array}{l}99.8 \\
99.5 \\
98.6 \\
97.6\end{array}$ \\
\hline
\end{tabular}

be appreciated that agreement of the data with either model does not constitute definite proof that desorption is controlled by first-order desorption reactions. As discussed above, because of the limitations of the methodology used in this study, transport processes may have had a significant influence on the rates of metal desorption. Nevertheless, bearing in mind their limitations, the use of such models is considered a useful technique to evaluate the kinetic events observed in this study.

Tables 4 and 5 show the various parameters derived from fitting the experimental data to Eq. [1] and[2]. Rather than show values for the various rate constants, the half-lives $\left(t_{0.5}\right)$ for the reactions are presented (time required for half of the original sorbed metal to be desorbed). These were calculated from the values for $k$ as described by Sparks (1989). In the case of Eq. [1], $t_{0.5}\left(k_{1}\right)$ represents the half-life for a fairly rapid desorption reaction with values of $<1 \mathrm{~h}(0.03-0.37 \mathrm{~h})$ and $t_{0.5}\left(k_{2}\right)$ represents the half-life for a much slower desorption reaction with a range of values between 2.78 and $29.81 \mathrm{~h}$. There was no significant difference in $t_{0.5}\left(k_{1}\right)$ values between the two clays for either $\mathrm{Cd}$ or Co desorption and, with the exception of $\mathrm{Cd}$ desorption from the Craigieburn clay (discussed separately below), no significant effect of contact period on $t_{0.5}\left(k_{1}\right)$ values. In contrast, values for $t_{0.5}\left(k_{2}\right)$ (half-life for the slower desorption reaction) were significantly $(P<0.01)$ higher with increasing length of sorption period. In addition, mean $t_{0.5}(k)$ values derived from Eq. [2] also increased significantly $(P<0.05)$ with increased sorption period (Tables 4 and 5). As discussed previously (Backes et al., 1995), such changes are indicative of a movement of $\mathrm{Cd}$ and Co ions to more slowly desorbing sites, or alternatively result from slower intraparticle diffusion rates associated with the movement of ions to more inaccessible sites.

In the case of $\mathrm{Cd}$ sorbed by the Craigieburn clay fraction, the fit to Eq. [1] suggested that increasing the initial sorption period also increased the proportion of sorbed $\mathrm{Cd}$ associated with the slower of the two reactions $\left(C_{2}\right.$, see Table 4$)$. A similar change was observed for both Cd and Co sorbed by goethite (Backes et al., 1995). However with the Craigieburn clay, there was also a significant $(P<0.01)$ decrease in the value of $t_{0.5}\left(k_{1}\right)$ (half-life for the faster of the two desorption reactions) with increasing sorption period (Table 4). This is somewhat difficult to explain, as is the apparent decrease with increasing sorption period in the proportion of sorbed $\mathrm{Cd}$ associated with the slower of the two reactions for the Wakanui clay (Table 4). In the case of the Wakanui soil, however, the apparent anomaly might possibly be explained by the difference in $\mathrm{pH}$ between samples subjected to the 1- and 16-wk sorption periods. The 1-wk sorption period samples had $\mathrm{pH}$ values on average $0.2 \mathrm{pH}$ units higher than the 16-wk samples (Table 2).

The apparent inconsistencies discussed above emphasize the need for a cautious approach to the interpretation of data when applying the type of simplistic model that is embodied in Eq. [1]. In this study, the analysis of data obtained by application of the lognormal model allows a less ambiguous interpretation. Mean $t_{0.5}(k)$ values, derived from fitting $\mathrm{Eq}$. [2] to experimental data for $\mathrm{Cd}$ and Co desorption from either clay fraction, show consistent decreases with increasing sorption period. It should also be noted that the lognormal model requires only two fitted parameters, compared with the three required for the two-discrete-sites model.

\section{CONCLUSIONS}

As with the previous study involving synthetic $\mathrm{Fe}$ and Mn oxides (Backes et al., 1995), it has been shown that substantial proportions of the $\mathrm{Cd}$ and $\mathrm{Co}$ sorbed by two soil clay fractions cannot readily desorb back into solution. It was also shown that increasing the contact period between metal and clay material resulted in decreased rates of metal desorption, implying that reactions had not reached equilibrium even though no further metal ions were adsorbed. Both kinetic models used in the study gave excellent fits to the experimental data. In general, although some caution should be used regarding their interpretation, changes with increasing sorption period in parameters derived from the models suggested a movement of $\mathrm{Cd}$ and Co to slower desorption reactions.

The results from this study provide further evidence for the continuing slow reaction of metal ions with soils following sorption from solution, and suggest that the bioavailability of metals added to soils as trace element fertilizers or as contaminants may decrease with time. 


\section{ACKNOWLEDGMENTS}

C.A. Backes thanks the New Zealand University Grants Committee for the award of a postdoctoral scholarship, during the tenure of which this research was carried out. The technical assistance of L.J. Hassall is gratefully acknowledged.

\section{REFERENCES}

Backes, C.A., R.G. McLaren, A.W. Rate, and R.S. Swift. 1995. Kinetics of cadmium and cobalt desorption from iron and manganese oxides. Soil Sci. Soc. Am. J. 59:778-785.

Barrow, N.J., J. Gerth, and G.W. Bruemmer. 1989. Reaction kinetics of the adsorption and desorption of nickel, zinc and cadmium by goethite. II. Modelling the extent and rate of reaction. J. Soil Sci. 40:437-450.

Blakemore, L.C., P.L. Searle, and B.K. Daly. 1987. Methods for chemical analysis of soils. Sci. Rep. 80. N.Z. Soil Bureau, Lower Hutt, New Zealand

Bruemmer, G.W., J. Gerth, and K.G. Tiller. 1988. Reaction kinetics of the adsorption and desorption of nickel, zinc and cadmium by goethite. I. Adsorption and diffusion of metals. J. Soil Sci. 39:37-52.

Carski, T.H., and D.L. Sparks. 1985. A modified miscible displacement technique for investigating adsorption-desorption kinetics in soils. Soil Sci. Soc. Am. J. 49:1114-1116.

Dang, Y.P., R.C. Dalal, D.G. Edwards, and K.G. Tiller. 1994. Kinetics of zinc desorption from Vertisols. Soil Sci. Soc. Am. J. 58: 1392-1399.

Forbes, E.A., A.M. Posner, and J.P. Quirk. 1976. The specific adsorption of divalent $\mathrm{Cd}, \mathrm{Co}, \mathrm{Cu}, \mathrm{Pb}$ and $\mathrm{Zn}$ on goethite. J. Soil Sci. 27: 154-166.

Gee, G.W., and J.W. Bauder. 1986. Particle-size analysis. p. 383-411 In A. Klute (ed.) Methods of soil analysis. Part 1. 2nd ed. Agron. Mongr. 9. ASA and SSSA, Madison, WI.

Kabata-Pendias, A., and H. Pendias. 1992. Trace elements in soils and plants. 2nd ed. CRC Press, Boca Raton, FL.

Kaiser, M.L., S.R. Koirtyohann, and E.J. Hinderberger. 1981. Reduction of matrix interferences in furnace atomic absorption with the L'Vov platform. Spectrochim. Acta 36B:773-783.

Kerndorff, H., and M. Schnitzer. 1980. Sorption of metals on humic acid. Geochim. Cosmochim. Acta 44:1701-1708.
Kinniburgh, D.G., M.L. Jackson, and J.K. Syers. 1976. Adsorption of alkaline earth, transition and heavy metal cations by hydrous gels of iron and aluminium. Soil Sci. Soc. Am. J. 40:796-799.

Kuo, S., and D.S. Mikkelsen. 1980. Kinetics of zinc desorption from soils. Plant Soil 56:355-364.

Lehmann, R.G., and R.D. Harter. 184. Assessment of copper-soil bond strength by desorption kinetics. Soil Sci. Soc. Am. J. 48: $769-772$.

McLaren, R.G., D.M. Lawson, and R.S. Swift. 1986. Sorption and desorption of cobalt by soils and soil components. J. Soil Sci. 37: 413-426.

Rate, A.W., R.G. McLaren, and R.S. Swift. 1992. Evaluation of a lognormal distribution first-order kinetic model for copper(II)-humic acid complex dissociation. Environ. Sci. Technol. 26:2477-2483.

Rate, A.W., R.G. McLaren, and R.S. Swift. 1993. Response of copper(II)-humic acid dissociation kinetics to factors influencing complex stability and macromolecular conformation. Environ. Sci Technol. 27:1408-1414.

Shuman, L.M. 1982. Separating soil iron- and manganese-oxide fractions for microelement analysis. Soil Sci. Soc. Am. J. 46:1099-1102.

Sparks, D.L. 1989. Kinetics of soil chemical processes. Academic Press, New York.

Stevenson, F.J. 1982. Humus chemistry, genesis, composition, reactions. John Wiley \& Sons, New York.

Swift, R.S., and R.G. McLaren. 1991. Micronutrient adsorption by soils and soil colloids. p. 257-292. In G.H. Bolt et al. (ed.) Interactions at the soil colloid-soil solution interface. Kluwer Academic Publ., Dordrecht, the Netherlands.

Tate, K.R., and B.K.G. Theng. 1980. Organic matter and its interactions with inorganic soil constituents. p. 225-249. In B.K.G. Theng (ed.) Soils with variable charge. N.Z. Soc. Soil Sci., Lower Hutt, New Zealand.

Tiller, K.G., J. Gerth, and G. Brümmer. 1984. The sorption of Cd, $\mathrm{Zn}$ and Ni by soil clay fractions: procedures for partition of bound forms and their interpretation. Geoderma 34:1-16.

Tipping, E., and M.A. Hurley. 1992. A unifying model of cation binding by humic substances. Geochim. Cosmochim. Acta 56:36273641 .

Willis, B.G., W.H. Woodruff, J.R. Frysinger, D.W. Margerum, and H.L. Pardue. 1970. Simultaneous kinetic determination of mixtures by on-line regression analysis. Anal. Chem. 42:1350-1355. 